\title{
Cortical Connectivity Suggests a Role in Limb Coordination for Macaque Area PE of the Superior Parietal Cortex
}

\author{
Sophia Bakola, ${ }^{1,2}$ Lauretta Passarelli, ${ }^{1}$ Michela Gamberini, ${ }^{1}$ Patrizia Fattori, ${ }^{1}$ and Claudio Galletti ${ }^{1}$ \\ ${ }^{1}$ Department of Pharmacy and Biotechnology, University of Bologna, 40126 Bologna, Italy, and ${ }^{2}$ Department of Physiology, Monash University, Clayton, \\ Victoria 3800, Australia
}

In macaques, superior parietal lobule area 5 has been described as occupying an extensive region, which includes the caudal half of the postcentral convexity as well as the medial bank of the intraparietal sulcus. Modern neuroanatomical methods have allowed the identification of various areas within this region. In the present study, we investigated the corticocortical afferent projections of one of these subdivisions, area PE. Our results demonstrate that PE, defined as a single architectonic area that contains a topographic map of the body, forms specific connections with somatic and motor fields. Thus, PE receives major afferents from parietal areas, mainly area 2, PEc, several areas in the medial bank of the intraparietal sulcus, opercular areas PGop/PFop, and the retroinsular area, frontal afferents from the primary motor cortex, the supplementary motor area, and the caudal subdivision of dorsal premotor cortex, as well as afferents from cingulate areas PEci, 23, and 24. The presence and relative strength of these connections depend on the location of injection sites, so that lateral PE receives preferential input from anterior sectors of the medial bank of intraparietal sulcus and from the ventral premotor cortex, whereas medial PE forms denser connections with area PEc and motor fields. In contrast with other posterior parietal areas, there are no projections to PE from occipital or prefrontal cortices. Overall, the sensory and motor afferents to PE are consistent with functions in goal-directed movement but also hint at a wider variety of motor coordination roles.

\section{Introduction}

Neurophysiological research in macaques and imaging studies in humans have implicated the superior parietal lobule in the sensory guidance of actions (Culham et al., 2006; Caminiti et al., 2010). Whereas the superior parietal lobule has been traditionally regarded as encompassing area 5, more recent studies have identified a mosaic of distinct architectonic areas (Pandya and Seltzer, 1982; Lewis and Van Essen, 2000a). The most extensive of these areas is $\mathrm{PE}$, which resides mainly on the exposed postcentral gyrus, directly caudal to the somatosensory cortex (Fig. 1).

Electrophysiological mapping in the location of PE has revealed the existence of a rough topographic organization, largely parallel to that of the anterior somatosensory fields, with leg, trunk, and arm representations in mediolateral sequence (Taoka et al., 1998, 2000; Padberg et al., 2007). The cardinal feature of area $\mathrm{PE}$ is the wide representation of the arm and hand, a specialization that has been linked to the manual abilities of primates (Krubitzer and Disbrow, 2008). Indeed, a series of influential single-unit recording experiments in awake monkeys has shown that most neurons respond to proprioceptive stimulation, with

Received 0ct. 3, 2012; revised March 3, 2013; accepted March 8, 2013

Author contributions: S.B., P.F., and C.G. designed research; S.B., L.P., and M.G. performed research; S.B., L.P., and M.G. analyzed data; S.B. and C.G. wrote the paper.

This work was supported by Ministero dell'Università e della Ricerca EU FP7-IST-217077-EYESHOTS, Fondazione del Monte di Bologna e Ravenna, Italy, and the Australian National Health and Medical Research Council (1020839). We thank Prof. Marcello Rosa for critical comments on the manuscript.

The authors declare no competing financial interests.

Correspondence should be addressed to Dr. Claudio Galletti, Department of Pharmacy and Biotechnology, University of Bologna, Piazza di Porta San Donato, 2, 40126, Bologna, Italy. E-mail: claudio.galletti@unibo.it.

DOI:10.1523/JNEUROSCI.4685-12.2013

Copyright $\odot 2013$ the authors $\quad 0270-6474 / 13 / 336648-11 \$ 15.00 / 0$ fewer cells active for tactile and visual stimulation and to active reaches (Duffy and Burchfiel, 1971; Sakata et al., 1973; Mountcastle et al., 1975; for review, see Hyvärinen, 1982). Motor activity in area 5 neurons persists even in the absence of sensory stimulation, suggesting that it is internally generated (Seal et al., 1982). Accordingly, a number of subsequent studies have confirmed that area 5 neurons are involved in the preparation of movement (Burbaud et al., 1991) and in generating body-, shoulder-, or hand-center coordinates for reaching (Ferraina and Bianchi, 1994; Lacquaniti et al., 1995; Kalaska, 1996; Graziano et al., 2000; Bremner and Andersen, 2012).

In line with the physiological findings, early connectional studies in macaques showed that area 5 is closely connected to somatosensory and primary motor cortex (Jones et al., 1978; Pandya and Seltzer, 1982; Johnson et al., 1996). However, previous studies were either not strictly limited to the architecturally defined area PE or involved only a limited number of injections (Pons and Kaas, 1986). Thus, in the present study, we investigated the projections to the cytoarchitectonically defined area PE by placing retrograde tracer injections in different parts of $\mathrm{PE}$, including those located outside the predominant representation of the forelimb (Padberg et al., 2007). Our approach stemmed from an earlier observation that the heterogeneity of PE neural responses might be reflected in the diversity of connections for various sectors (Pons et al., 1985). Our results demonstrate that area $\mathrm{PE}$ is unified by a consistent pattern of afferents from the same cortical areas. However, they also reveal that the lateral part of PE (upper body/forelimb representation) shows a number of connections that distinguishes it from the medial part of PE (lower body representation), in line with the hypothesis that co- 


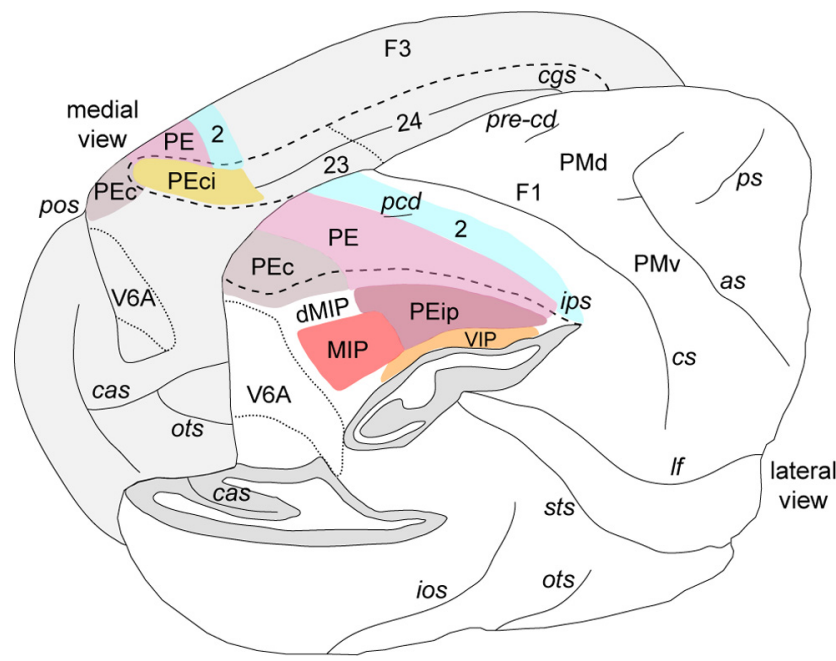

Figure 1. Summary illustration of the organization of posterior parietal cortex (modified from the study by Galletti et al., 1999). Posterior-lateral view of macaque brain showing the extent of area PE and surrounding parietal fields. The adjacent medial view of the brain is illustrated in gray. The lateral bank of the intraparietal sulcus (ips) has been removed to expose the areas of the medial bank. Major frontal and cingulate subdivisions, as used in the current analysis, are also noted. as, Arcuate sulcus; cas, calcarine sulcus; cgs, cingulate sulcus; cs, central sulcus; ios, inferior occipital sulcus; If, lateral fissure; ots, occipitotemporal sulcus; pcd, postcentral dimple; PMd, dorsal premotor cortex; PMv, ventral premotor cortex; pos, parieto-occipital sulcus; pre-cd, precentral dimple; ps, principle sulcus; sts, superior temporal sulcus.

ordination of forelimb and hindlimb and trunk muscles requires different sets of sensory inputs. In addition, present findings suggest the participation of $\mathrm{PE}$ in a wider range of sensorimotor integration tasks.

\section{Materials and Methods}

Experiments were conducted in 5 hemispheres of 4 male adult monkeys (Macaca fascicularis, 3-7 kg). All experimental protocols were approved by the Bioethical Committee of the University of Bologna and complied with the European Directive 86/609/EEC and with the Directive of 22 September 2010 (2010/63/EU) on the care and use of laboratory animals.

The animals were pretreated with atropine $(0.04 \mathrm{mg} / \mathrm{kg}, \mathrm{i} . \mathrm{m}$. $)$ and anesthetized with ketamine hydrochloride $(15 \mathrm{mg} / \mathrm{kg}$, i.m.) followed, after $30 \mathrm{~min}$, with sodium thiopental $(8 \mathrm{mg} / \mathrm{kg}$, i.v., with supplemental doses as required). To avoid edema, mannitol was administered intravenously $(1 \mathrm{~g} / \mathrm{kg})$. The university veterinary staff constantly monitored heart rate, blood pressure, respiratory depth, and body temperature. The animals were secured to a stereotaxic frame, and the dorsal surface of the superior parietal lobule was exposed. Injection sites were selected by direct visualization of the cortex and were assigned to areas after histological examination of postmortem material. Surgical procedures took place in standard aseptic conditions.

Fluorescent tracers were injected using a Hamilton microsyringe with a glass micropipette attached to its needle. These included cholera toxin $\mathrm{B}$ subunit (Invitrogen, $1 \%$ in PBS), conjugated with AlexaFluor-488 (CTB-green) or AlexaFluor-594 (CTB-red), and Fluororuby (Invitrogen). In one case, Fast Blue (Polysciences) was applied as crystal with the aid of a fine tungsten wire (Rosa et al., 2005). One case received two injections of HRP (Sigma-Aldrich). At the end of the surgery, the animals were allowed to recover before returning to their cage. Analgesics (ketorolac, $1 \mathrm{mg} / \mathrm{kg}$, i.m.) and antibiotics (erythromycin, $1-1.5 \mathrm{ml} / 10 \mathrm{~kg}$ ) were administered postoperatively.

After a survival period of $14 \mathrm{~d}$ ( $2 \mathrm{~d}$ in the case of HRP), the animals were preanesthetized with ketamine hydrochloride $(15 \mathrm{mg} / \mathrm{kg}$, i.m.) followed by a lethal dose of sodium thiopental intravenously. They were perfused transcardially first with 31 of saline and then with 51 of $4 \%$ paraformaldehyde ( $3.5 \%$ in the case of the HRP injection) in $0.1 \mathrm{M}$ phosphate buffer at $\mathrm{pH} 7.4$, and 41 of $5 \%$ glycerol in the same buffer. Brains
Table 1. Percentages of labeled neurons in different cortical areas after injections in PE

\begin{tabular}{llllllllc}
\hline & Areas & Case 1 & Case 2 & Case 4 & Case 5 & Case 6 & Case 3 & Case 7 \\
\hline Superior parietal lobule & PEc & 9.7 & 1.3 & 10.5 & 25.7 & 15.2 & 1.2 & $b$ \\
& dMIP & 9.3 & 2.6 & 0.1 & 1.6 & 1.7 & 0.5 & 3.4 \\
& MIP & 0 & $a$ & 0 & 0 & 0 & $a$ & $a$ \\
& PEip & 6.9 & 22.1 & 0.1 & 0.2 & 0 & 10.1 & 4.8 \\
& VIP & 0.2 & 2.0 & 0 & 0 & 0 & 2.6 & 0 \\
& AIP & 0 & 0 & 0 & 0 & 0 & $a$ & 0 \\
& 2v & 0 & 2.0 & 0 & 0 & 0 & 5.3 & 0 \\
Somatosensory cortex & 1 & 1.6 & 7.7 & 0.2 & 1.0 & 0.6 & 4.5 & 0 \\
& Frontal cortex & 26.7 & 14.4 & 21.3 & 28.3 & 4.6 & $c$ & 12.5 \\
& 3a & 1.9 & 8.7 & 0.1 & 0.8 & 0 & 21.6 & 6.3 \\
& 3b & 0.4 & 3.8 & 0.1 & 1.0 & 0 & 5.3 & 0 \\
& F1 & 14.7 & 12.7 & 49.0 & 8.4 & 19.9 & 10.9 & 9.4 \\
& F2 & 1.0 & 0.2 & 2.1 & 2.2 & 0.3 & 1.0 & 4.9 \\
& F3 & 3.0 & 1.9 & 7.9 & 13.9 & 23.1 & 1.6 & 17.1 \\
& PMv & 1.3 & 3.1 & 0.1 & 0 & 0 & 3.4 & 0 \\
& PEci & 4.4 & 0.3 & 0.7 & 4.6 & 2.4 & 0 & 15.6 \\
& 23 & 2.4 & 0.9 & 1.8 & 2.8 & 11.4 & 1.1 & 13.1 \\
& 24 & 2.0 & 4.2 & 2.3 & 0.2 & 6.5 & 3.5 & 3.0 \\
Lateral parietal cortex & PGop & 5.9 & 1.1 & 0 & 7.4 & 10.1 & 1.8 & 2.5 \\
& PFop & 1.6 & 3.8 & 0.2 & 0 & 0 & 2.4 & 0 \\
& PF & 0.8 & 0.3 & 0 & 0.4 & 0.3 & $a$ & 0 \\
& Ri & 5.8 & 5.9 & 3.4 & 1.2 & 3.1 & 12.7 & 7 \\
& SII & 0 & 0.8 & 0 & 0 & 0 & 7.2 & 0.1 \\
& Ins & 0.3 & 0.1 & 0.1 & 0.2 & 0.6 & 1.1 & 0.5 \\
& Tpt & 0.2 & 0.2 & 0 & 0 & 0.1 & 2.1 & 0 \\
\hline
\end{tabular}

${ }^{a}$ Labeled cells $<0.1 \%$ of total.

${ }^{b}$ Injection site in case 7 includes area PEC.

Injection site in case 3 includes area 2.

were removed from the skull, photographed from all views, and cryoprotected by immersion into buffered glycerol solutions of $10 \%$ and then $20 \%$ until they sank ( $4-5 \mathrm{~d}$ in total). The brains were then frozen in isopentane and stored at $-80^{\circ} \mathrm{C}$. Sections of $60 \mu \mathrm{m}$ were cut on a freezing

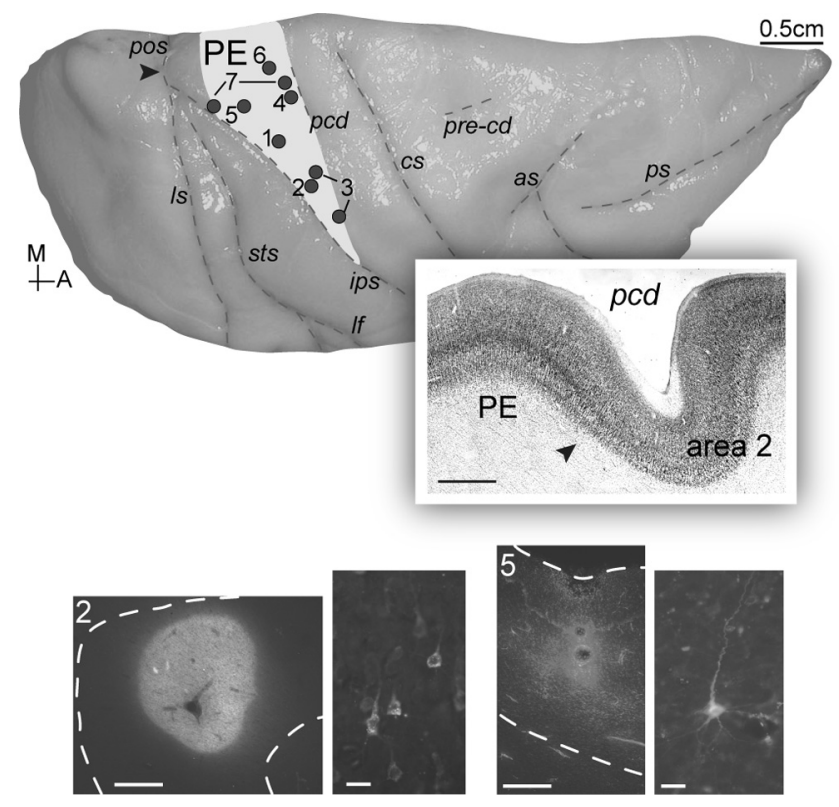

Figure 2. Summary of injection sites and architectonic features of PE. Top, Dorsolateral view of a single macaque hemisphere showing the approximate location of injection sites (dark gray circles, 1-7). Dashed lines indicate major sulci. Is, Lunate sulcus. Inset, The cytoarchitectonic pattern of area PE at the border with area 2. High-magnification view from Nissl-stained parasagittal section at the level indicated with the arrow on the brain photograph at the top. Scale bar, 1 $\mathrm{mm}$. Bottom insets, Examples of injection sites and labeled cells. 2, CTB-green injection in case 2 and green-labeled cells in area PEip; 5 , Fluororuby injection in case 5 and red-labeled cell in area 2. Scale bars: injection sites, $500 \mu \mathrm{m}$; labeled cells, $40 \mu \mathrm{m}$. Other details are as in Figure 1 . 


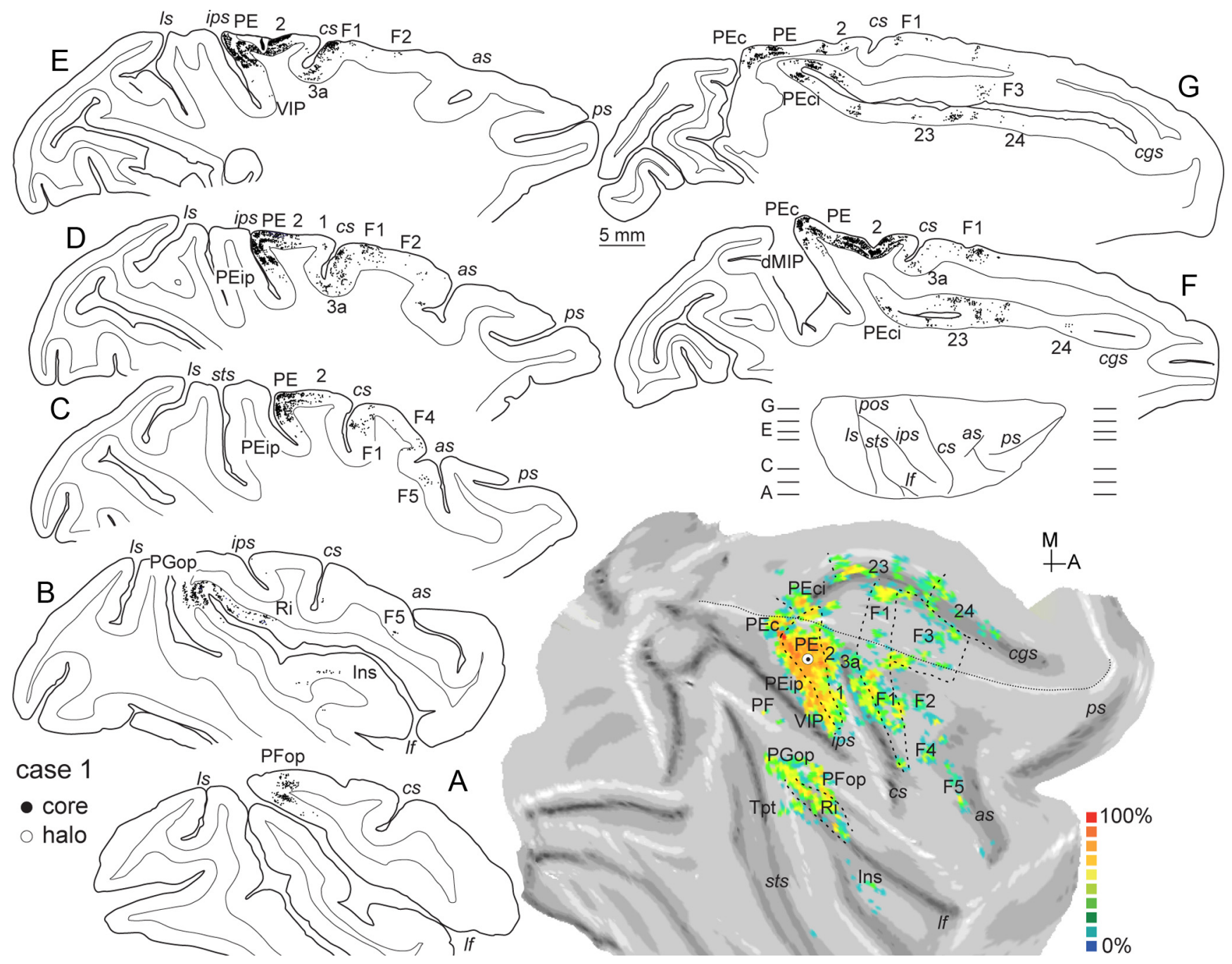

Figure 3. Location of injection site in lateral PE (case 1) and cortical distribution of retrograde-labeled cells. Sagittal sections (A-F) were taken at the levels indicated on the brain silhouette. Bottom right, Two-dimensional reconstruction illustrating the distribution and density of labeled cells in case 1. Color scale indicates the relative density of labeled cells, counted within $600 \times 600$ $\mu \mathrm{m}$ units, as a percentage of the maximum unit value. Darker shades of gray on the flat maps represent sulcal depth; intermediate shades of gray, cortical convexity; white color, sulcal lip. This and subsequent flat maps illustrate both the lateral and medial surfaces of the cortex; the stippled line marks the transition between lateral (below line) and medial (above) surface. A, Anterior; $\mathrm{M}$, medial. Other details are as in Figures 1 and 2.

microtome, in the parasagittal (majority of cases) or coronal (one case) planes, and were collected in five series. The first series was left unstained for fluorescent observation. For visualization of HRP, we used the tetramethyl-benzidine method (Mesulam and Rosene, 1979). Subsequent series were stained for Nissl substance (thionin, $0.1 \%$ in $0.1 \mathrm{~m}$ acetate buffer, pH 3.7) and for myelin (Gallyas, 1979). All sections were coverslipped with DPX, after dehydration in ethanol and clearing with xylene.

Data analysis. Fluorescent material was examined under a Zeiss Axioscope equipped with $10 \times$ and $20 \times$ objectives. The location of labeled neurons and the outline of the sections were plotted using custom-made software with the aid of $\mathrm{X} / \mathrm{Y}$ transducers mounted on the microscope stage. In all sections analyzed, the entire ipsilateral cortex was examined for retrograde labeling. For each injection, labeled neurons in various cortical areas were charted in every second section; the number of labeled cells in each cortical area was expressed as a fraction of the total number of cells for that injection (excluding labeled cells in area PE, as those formed intrinsic label). We used the Kendall coefficient of concordance W (Siegel, 1956; Legendre, 2005), a nonparametric statistical method, to examine the consistency in the distribution of label across different injections. As recently discussed in detail (Reser et al., 2012), nonparametric statistical methods are preferred when normal distributions of variables cannot be assumed; this is often the case in neuroanatomical studies in which factors, such as relative small sample sizes and variability in transport characteristics of tracers, make inappropriate the use of classical parametric statistics. For the current analysis, we grouped projections from different areas into five cortical sectors (Table 1) to correct for large differences in the total number of labeled cells and for zero/low cell counts. The obtained value of Kendall's coefficient of concordance, $\mathrm{W}$, was tested for significance with adjusted $\chi^{2}$ statistics (Friedman's $\chi^{2}$ ), a reasonably satisfactory approach for moderate/small sample sizes (Sheskin, 2004).

Two- and three-dimensional reconstructions of cortex were obtained with the CARET software (Van Essen et al., 2001), from mid-thickness section contours, according to the procedures described previously (Galletti et al., 2005; Gamberini et al., 2009). The same software was used to prepare the density maps of labeled neurons by projecting the location of each neuron to the nearest mid-thickness contour (Bakola et al., 2010; Passarelli et al., 2011), along with marks noting the architectonic borders of cortical areas.

Area parcellation. We carefully examined our histological material to ensure that injections were confined to a single architectonic area. The main characteristic of area PE, which distinguishes it from adjacent cortices, is the presence of large pyramids in layers III and V. However, as it has been reported before, PE shares this feature with area 2, which lies immediately anterior, making the accurate placement of a border between the two areas "especially vexing" (Burton and Fabri, 1995). To 


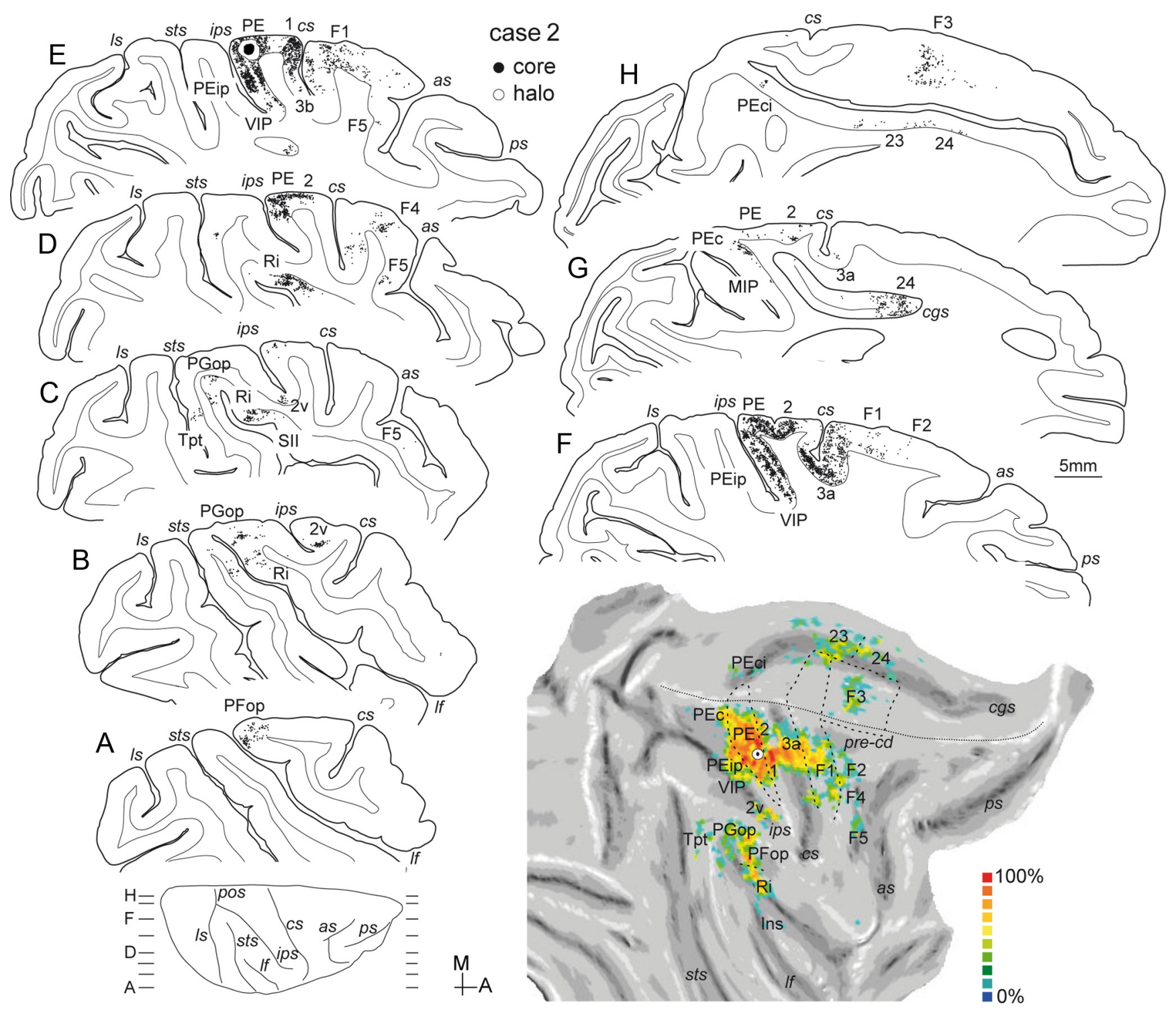

Figure 4. Location of the (TB-green injection site in lateral PE (case 2) and cortical distribution of retrograde-labeled cells. Sagittal sections $(\boldsymbol{A}-\boldsymbol{F})$ were taken at the levels indicated on the brain silhouette shown at the bottom left. Bottom right, Two-dimensional reconstruction illustrating the distribution of labeled cells in case 2. Other details are as in Figures 1 and 2.

disambiguate this border, we found the description by Jones et al. (1978) extremely reliable. According to these authors, area $5(\mathrm{PE})$ has a thinner layer IV but a rather homogeneous cell population, which makes it more distinguishable even under low magnification (Fig. 2, right inset). This architectural feature allowed us to place the rostral border with area 2 in good agreement with earlier studies (Pons et al., 1985; Taoka et al., 1998; Lewis et al., 1999).

The borders of area PE and of caudal and medial neighboring areas PEc and PEci (supplementary somatosensory area) (Murray and Coulter, 1981) were defined according to the architectonic criteria of Pandya and Seltzer (1982). Anterior somatosensory areas were designated according to Jones et al. (1978) and Lewis et al. (1999). The inferior parietal lobule was parcellated according to Pandya and Seltzer (1982) and Gregoriou et al. (2006). The lateral sulcus was subdivided according to Pandya and Seltzer (1982) and Robinson and Burton (1980). The identification of the areas in the cingulate sulcus was based on previous descriptions by several authors (Matelli et al., 1991; Morecraft et al., 2004; Vogt et al., 2005). The premotor cortex was subdivided following the criteria of Matelli et al. (1991) and Geyer et al. (2000). In a few cases (e.g., when the plane of sectioning was not favorable), assignment relied primarily on location relative to sulcal landmarks, using the above reports as a guide.
Digital photographs were acquired with a Zeiss AxioCam and the AxioVision version 4.4 software (Carl Zeiss). Figures were prepared with Adobe Illustrator and Photoshop (Adobe Systems). This involved adjusting brightness/contrast, scaling of original drawings to appropriate size, and compiling individual figures to construct composite illustrations. Raw data were not altered by these manipulations.

\section{Results}

Here we describe the pattern of connections of parietal architectonic area PE. Our findings are based on the analyses of 7 cases in 5 macaque hemispheres that collectively covered most of the extent of the area. Figure 2 presents a summary of the locations of injection sites and examples of injections and retrograde labeled cells. According to previously published mappings, this cortical region hosts almost the full representation of body parts (with the possible exception of the head, Padberg et al., 2007), with lower body located medially, upper body laterally, and a representation of the trunk in-between. The lateral tip of the postcentral dimple marks the approximate location of the trunk representation (Taoka et al., 1998, 2000); we used this macroanatomical land- 

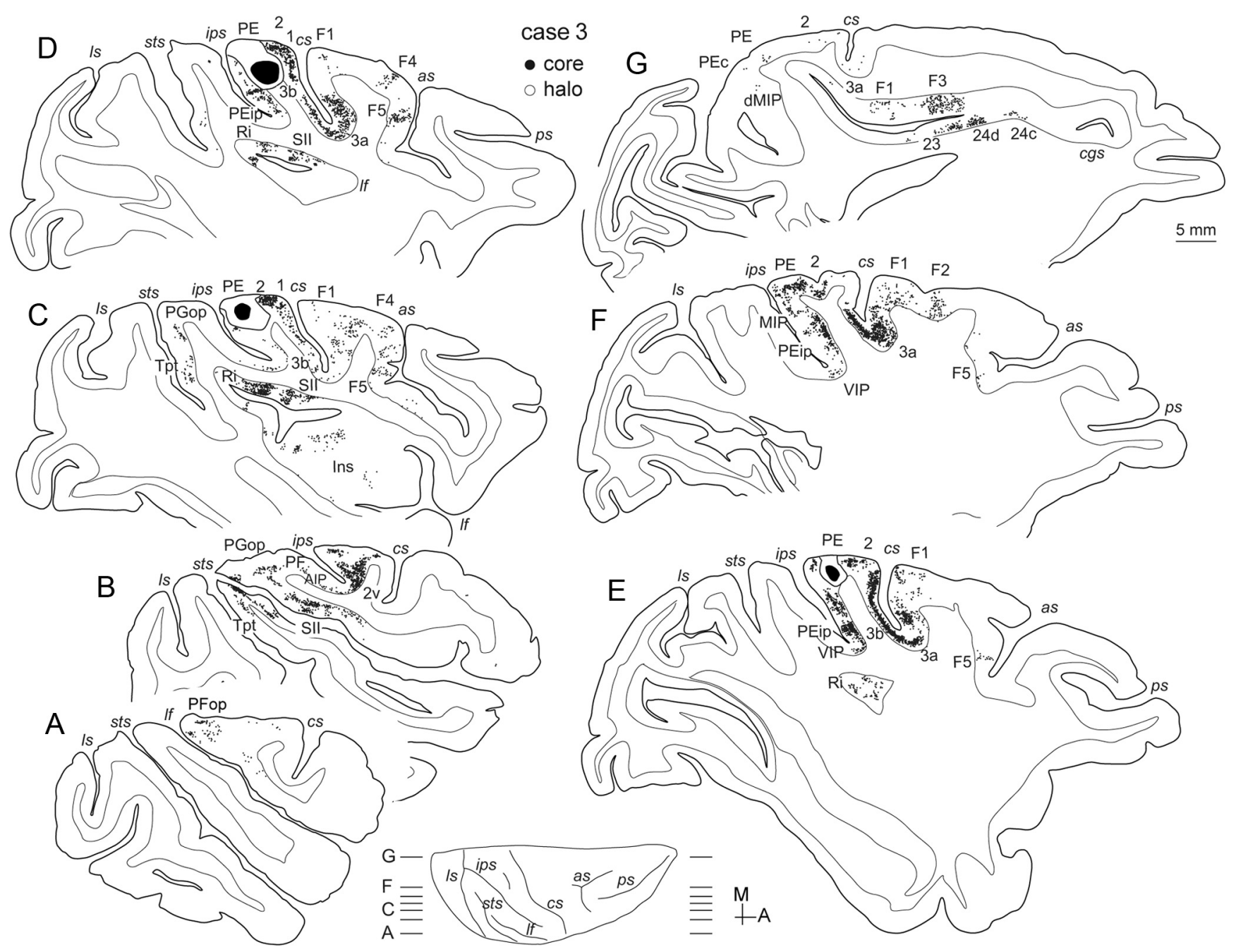

Figure 5. Location of the HRP injection sites in lateral PE/area 2 (case 3) and cortical distribution of retrograde-labeled cells. Sagittal sections $(\boldsymbol{A}-\boldsymbol{E})$ were taken at the levels indicated on the brain silhouette shown at the bottom. Other details are as in Figures 1 and 2.

mark to group PE injections into "lateral" and "medial" ones, in an attempt to examine whether upper (trunk/forelimb)- and lower-body fields of the same area receive different sets of cortical input. At this point, we should note that we applied this criterion to better illustrate our findings, and any observations regarding somatotopic relationships are based solely on published maps of PE because we did not verify injection sites with physiological methods. We first present our results obtained after injections in lateral parts of $\mathrm{PE}$, followed by results after injections in medial PE.

\section{Lateral injections}

In three cases, we placed tracer injections in lateral locations of $\mathrm{PE}$ (Fig. 2, cases 1-3), within the expected representations of the trunk/arm. Histological examination of our material showed that two of these injections (cases 1 and 2) were restricted within the cortex and the borders of PE, whereas case 3 involved two large injections of HRP, which partly spread to the underlying white matter and surrounding area 2 and, thus, was excluded from quantitative analyses. Nevertheless, results from this case shared several characteristics with the other two cases and are therefore presented together, with the few differences highlighting possible distinctions between PE and adjacent fields. Table 1 reports the percentages of labeled cells in different cortical areas after injec- tions in case $1(13,925$ labeled cells outside PE), case $2(17,315$ cells excluding cells in PE), and case 3 (44,008 cells, excluding cells in PE and area 2). Figures 3, 4, and 5 illustrate the areal distribution of retrograde label for these three cases. The densest and most consistent projections were observed from somatosensory area 2, whereas smaller amounts of label originated from the other subdivisions of postcentral cortex (areas 1, 3a, and 3b). Additional labeled cells were observed in superior parietal area $\mathrm{PEc}$ and in the medial bank of the intraparietal sulcus, particularly in its anterior half (area PEip, Matelli et al., 1998). Label in this cortical region became more conspicuous as the injection was placed in further lateral PE locations (compare Fig. 3 with Figs. 4 and 5). In contrast, the caudal half of the medial bank revealed moderate label, in its dorsalmost third, in a likely distinct field we have previously named dMIP (Bakola et al., 2010), whereas area MIP proper contained only some isolated cells (Fig. $4 G)$. Deeper in the intraparietal sulcus, few cells were observed in area VIP, confirming earlier observations (Lewis and Van Essen, 2000b). Area AIP, in the lateral bank of the intraparietal sulcus, contained scattered cells only after the big HRP injection that included area 2 (Fig. $5 B$ ), suggesting that label might be the result of the involvement of this area into the injection site. Previous anatomical results have been equally inconclusive, with connections between AIP and both areas 5 and 2 present in one study 
(Lewis and Van Essen, 2000b) but not in in another (Borra et al., 2008). Finally, the more lateral of our cases ( 2 and 3 ) showed additional labeled cells around the tip of the intraparietal sulcus, in the somatic-vestibular area $2 \mathrm{v}$ (e.g., Fig. 4 flat map; Fig. 5B).

In the somatosensory fields of the lateral sulcus, labeled cells were found in areas PGop and PFop, with few neurons in area PF (Fig. 3, flat map; Fig. 5B). Inferior parietal projections were thus restricted to the opercular fields that line the lip of the lateral fissure and tended to avoid classical subdivisions of area 7. In the depths of the lateral sulcus, labeled cells were found in the vestibular retroinsular (Ri) cortex, and, in much smaller numbers, in the adjacent insular (Ins) cortex. In case 2, few labeled cells arose from the second somatosensory area (SII, Fig. 4C). These were more numerous in case 3 with the large HRP injection that slightly spread into white matter and adjacent fields (Fig. $5 B, C$ ). Based on previous studies (Jones et al., 1978; Friedman et al., 1980; Pons and Kaas, 1986), it could be that SII labeling comes from an involvement of area 2 into the injection site. Finally, in all cases, scattered labeled cells were found in the multimodal caudal temporoparietal transition area Tpt.

In the frontal lobe, label was consistently shown in the primary motor cortex (F1/M1), both within the anterior bank of the central sulcus and the exposed gyral surface. Additional labeled cells originated in medial (SMA/F3), dorsal (area F2), and ventral (areas F4 and F5) premotor cortex. On the whole, projections from premotor fields were relatively weak compared with the heavier input from primary motor cortex.

In the medial cortex, moderate label was observed in and around the cingulate sulcus. In caudorostral sequence, labeled cells were found in areas PEci, 23, and 24, in all three cases.

A notable characteristic of these lateral injections was that labeling extended into large portions of areas with well-known topography, likely encompassing both upper and lower-body representations. For example, in case 1, labeled cells in area 2 spanned almost its full mediolateral extent, sparing only its most lateral part (Fig. 3, flat map). Likewise, labeled cells occupied the rostral part of area 23 (in the putative forelimb representation) (Hutchins et al., 1988), extending to more caudal locations, particularly in case 1 . This finding could reflect tracer leakage into medial PE locations; however, our injection sites were relatively small (Fig. 2). An alternative interpretation would be that the upper-limb field in area PE receives both homotopic and heterotopic input from somatomotor cortices, similar to what has been observed in area 3a (Huffman and Krubitzer, 2001). Such diverse input could be, for instance, useful in maintaining balance during fast movement.

\section{Medial injections}

In four cases, we placed injections at medial locations in PE (cases 4-7; Fig. 2), at the expected locations of the lower body representations. As illustrated in Figure 2, case 7 received two CTB-red injections; the posterior one slightly invaded area PEc and was therefore excluded from the average analyses. However, we describe it together with the other cases because results were qualitatively similar.

Compared with the lateral cases, our injections in medial sectors of PE resulted in lower numbers of labeled cells (case 4, 3124; case 5,498 ; case 6,3567$)$. Nevertheless, the distribution of label in parietal and frontal cortices resembled the basic pattern observed after lateral injections, described above, with few exceptions. The relative density of projections from various cortical areas is reported in Table 1, whereas examples of the spatial distribution of labeled cells in three medial cases are shown in Figures 6, 7, and 8A. Case 5,

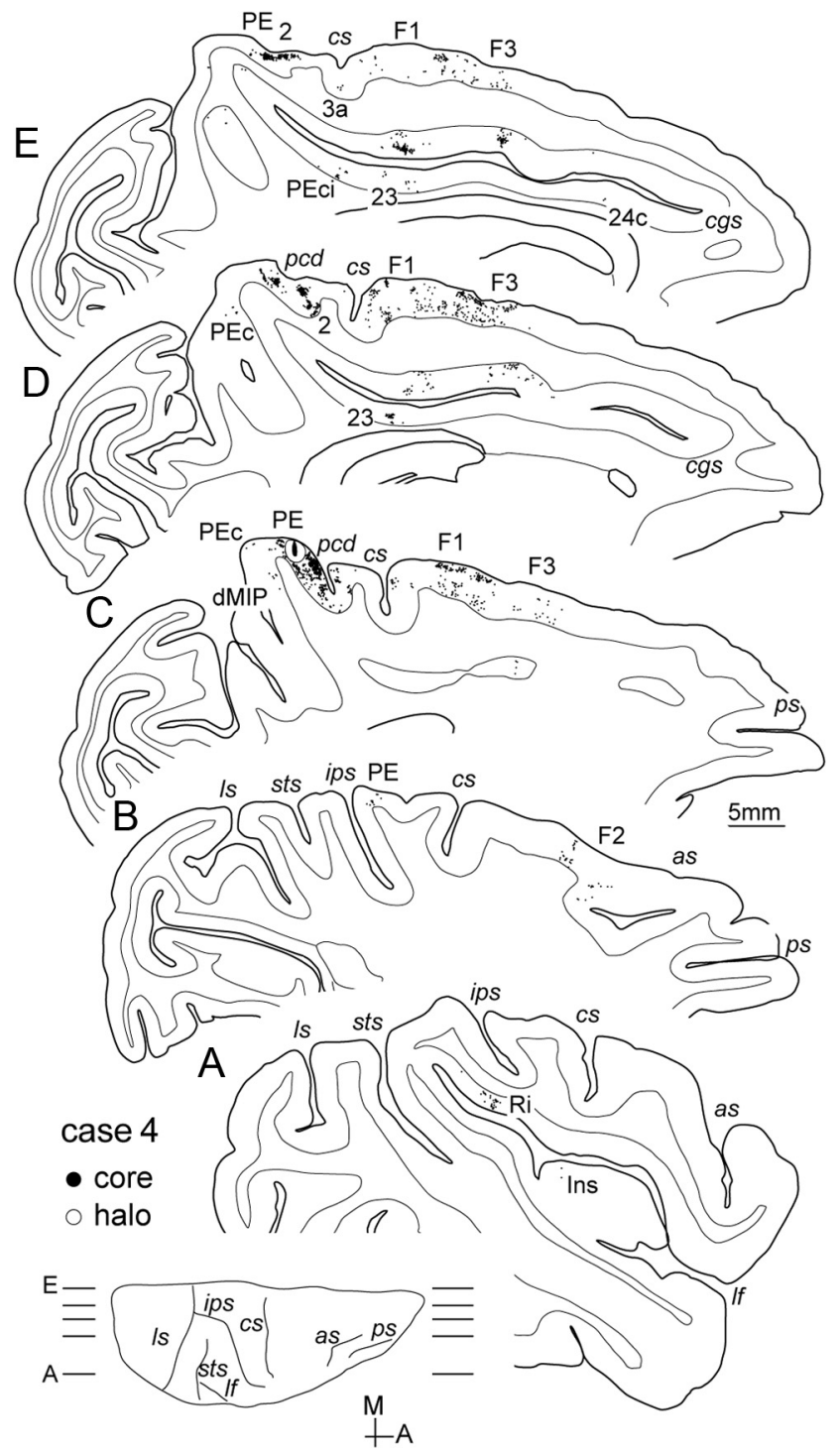

Figure 6. Location of the CTB-green injection site in medial PE (case 4) and cortical distribution of labeled cells. Sagittal sections $(\boldsymbol{A}-\boldsymbol{E})$ were taken at the levels indicated on the brain silhouette shown at the bottom. Other details are as in Figures 1 and 2 .

which contained the smallest proportion of extrinsic label, is not illustrated but was included in the quantitative analyses.

Similar to the lateral cases, injections involving medial parts of PE revealed a high proportion of labeled cells in somatosensory area 2 . In the medial cases, however, labeled cells were confined in the more medial part of area 2 (e.g., see Fig. $8 A$ ). The other postcentral areas $(1,3 \mathrm{a}$, and $3 \mathrm{~b})$ contributed fewer labeled cells (together accounting for $\sim 1 \%$ of total medial projections). In the superior parietal lobule, substantial label originated from area PEc and, to a lesser degree, from dMIP and MIP. In marked contrast to the lateral cases, label was extremely sparse in the anterior part of the medial bank of the intraparietal sulcus, in area PEip. In the inferior parietal lobule, the densest patches of cells were found in its caudalmost part, in area PGop, with sparse cells in anterior opercular area PFop, and the retroinsular and insular cortices of the lateral sulcus.

In the frontal lobe, labeled cells arose from primary motor cortex, in particular from its medial half, and from medial premotor area (SMA/F3), in the presumed location of the hindlimb representation (Fig. 8A, flat map) (Luppino et al., 1991). Label 
from both these areas was particularly high, accounting for $\sim 40 \%$ of total label after injections in medial PE. Smaller amounts of labeled cells were observed in the caudal superior premotor area F2, especially around the precentral dimple. Projections from F2 were stronger in case 7, which partially involved area PEc (compare flat maps of Figs. 7 and $8 A$ ), as expected from previous studies (Marconi et al., 2001; Bakola et al., 2010). Different to the lateral cases, injections in medial PE did not label cells in the ventral premotor cortex (areas F4 and F5), except for a few scattered cells in case 4 (Table 1).

The midline cortex was moderately labeled, similar to the cases with lateral injections. Labeled cells were observed in the caudal cingulate cortex, in areas PEci and 23 , as well as in anterior cingulate area 24. In case 7, projections from PEci and 23 were stronger than the average projections after injections in medial PE (Fig. 7, density map; Table 1), as expected after involvement of area PEc in the injection site (Bakola et al., 2010).

When considered together, our results show that all parts of PE receive fairly consistent extrinsic input from specific cortical regions. Indeed, statistical analysis of the distribution of labeled cells across the five injections restricted to the borders of $P E$ showed that results from various cases were similar $\left(\mathrm{W}=0.49, \chi^{2}=9.76, p<\right.$ 0.02 ). At the same time, several areas project with variable strengths to different sectors of PE. Figure $8 B$ allows a direct comparison between the areal distribution of label after two PE injections, a medial and a lateral one, performed in the same hemisphere. Apart from quantitative differences resulting from the different number of labeled cells in the two cases, there is good overlap of many labeled regions, but also differences between distributions. Among the latter, quite evident is the lacking in medial cases of labeling in area PEip, and in lateral parts of somatic sensory and motor/premotor areas (regions that represent the arm and/or the hand).

The average density of all significant cortical projections to $\mathrm{PE}(\geq 1 \%)$ is illustrated in the histogram in Figure 9 (top). The diagram in Figure 9 (bottom) summarizes the main connections of PE. Overall, area PE receives nearly $60 \%$ of its projections from the parietal areas that are mainly concerned with the elaboration of somatic sensation. Another 30\% arrives from specific sectors of frontal cortex, mainly from primary motor and medial premotor cortex. Smaller components originate from caudal and rostral parts of midline cortex, as well as from retro-insular cortex and other areas of the lateral parietal cortex. Although these connections emphasize a role in the guidance of skeletomotor activities, perhaps surprisingly, PE is not directly connected with the visuomotor parietal areas involved in reaching or grasping movements, such as V6A or AIP. The results also indicate a difference between PE and PEc, in terms of relative afference from motor versus premotor cortices (Bakola et al., 2010).

\section{Discussion}

Whereas the designation PE was first applied to an extensive region that largely overlapped with Brodmann's area 5 (e.g., von Bonin and Bailey, 1947), the current view is that this region is heterogeneous, with at least four subdivisions (Pandya and Seltzer, 1982), and probably more if one also considers the still poorly understood medial bank of the intraparietal sulcus (Colby et al., 1988; Matelli et al., 1998). Thus, the term $\mathrm{PE}$ is typically used to designate the smaller area we now report. There is evidence that subdivisions PE, PEc, PEip/PEa, and PEci can be distinguished based on projection patterns, as well as subtle cytoarchitectural differences (Pandya and Seltzer, 1982; Petrides and Pandya, 1984; Marconi et al., 2001; Morecraft et al., 2004; Bakola et al., 2010; present results) and response properties (Murray and Coulter, 1981; Breveglieri et al., 2006; Padberg et al., 2007). The picture that emerges from the above studies places PE, PEc, PEip, and PEci within the somatomotor realm of the parietofrontal network. Nevertheless, a thorough understanding of functional relationships is still lacking, given that most electrophysiological studies on this cortical sector have invariably used the broad term "area 5" (or "PRR" for medial parietal cortex) (Snyder et al., 1998).

The need for finer definition of cortical areas becomes more pressing if we consider that even histologically homogeneous areas, such as the primary sensory areas, or area MT, show some variation in their cortical input (Krubitzer and Kaas, 1990; Falchier et al., 2002; 


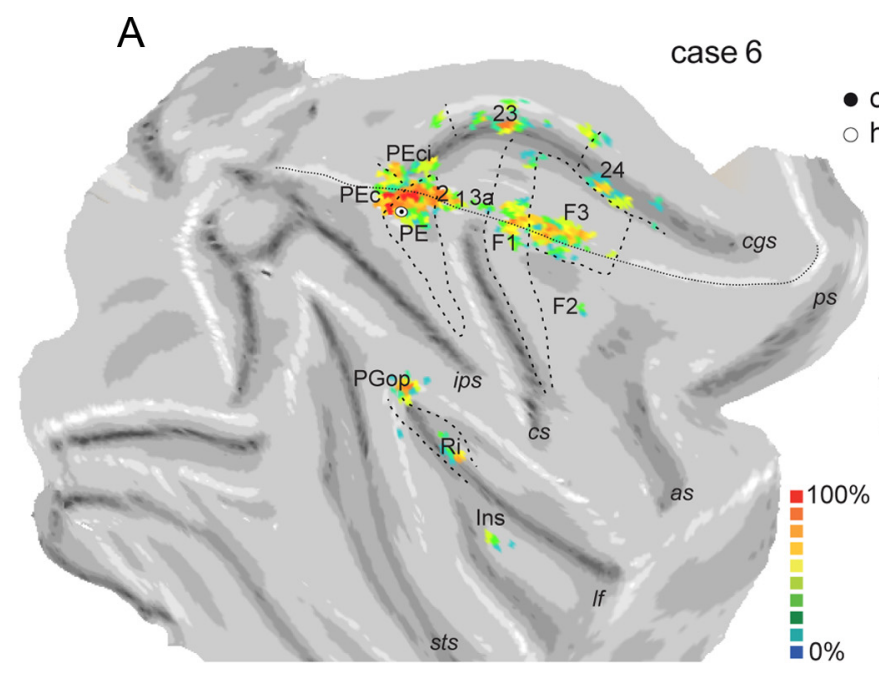

B

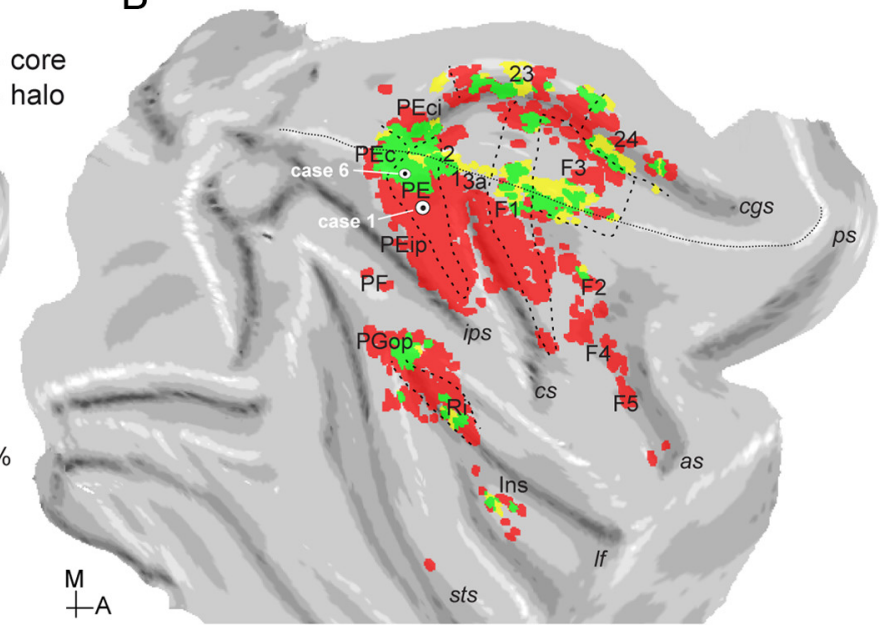

Figure 8. A, Two-dimensional reconstruction illustrating the distribution and density of label in case 6, that received a CTB-green injection at medial PE location. $\boldsymbol{B}$, Two-dimensional reconstruction illustrating the extent of label after a lateral injection (case 2) and a medial injection (case 6) in the same hemisphere. Although both cases showed significant overlap, the lateral case labeled additional cortical areas. Other details are as in Figures 1 and 2.

Palmer and Rosa, 2006). In the present study, we found that, regardless of the location of injection sites, PE, defined as a cytoarchitecturally uniform area, receives consistent projections from well-defined local and distant cortical networks. Our statistical analysis of the distribution of label in various cortical fields further supports the view that $\mathrm{PE}$ constitutes a single cortical area. In addition, compared with the other posterior parietal areas, PE displays some unique characteristics. As we show, PE is dominated by robust somatic afferents with weaker inputs from vestibular fields and the higherorder polysensory areas VIP and Tpt, whereas inputs from visual and prefrontal areas are practically absent. This result contrasts, for instance, with findings in superior parietal areas V6A and PGm that have more widespread connections, including connections with occipital, inferior parietal, and prefrontal cortices (Cavada and Goldman-Rakic, 1989a, 1989b; Gamberini et al., 2009; Passarelli et al., 2011). Equally significant are differences regarding motor input: PE emphasizes abundant projections from primary motor and medial premotor (SMA/F3) cortex, whereas posterior parietal areas connect preferentially with lateral subdivisions of premotor cortex (Matelli et al., 1998).

On the other hand, we observed regional variations in the pattern of projections that likely emphasize functional specializations within PE related to the representation of different body parts. Lateral parts of PE are preferentially targeted by areas PEip, $\mathrm{VIP}, 2 \mathrm{v}$ of the intraparietal sulcus, and ventral premotor areas, whereas medial parts of $\mathrm{PE}$ receive richer projections from $\mathrm{PEc}$, F1/M1, and F3/SMA. According to one interpretation, our results could be attributable to individual variability and/or tracer sensitivity. Given that ethical considerations restrict the use of large numbers of animals in this kind of research, our findings are based on relatively few cases that could potentially magnify regional variability. However, recent tracing studies in different species also describe considerable heterogeneity in the pattern of projections that arrive in association cortices (Burman et al., 2011; Markov et al., 2011). To conclude, the present findings suggest that area 5 constitutes a single cortical area with a mediolateral gradient of projections.

\section{Connections with somatosensory-related areas}

In agreement with previous studies (Pearson and Powell, 1978; Pandya and Seltzer, 1982; Pons and Kaas, 1986; Marconi et al.,
2001; Morecraft et al., 2004; Bakola et al., 2010), labeled cells projecting to PE were found in the surrounding somatosensoryrelated areas 2, PEc, PEci/supplementary somatosensory area, as well as in opercular areas PGop/PFop, and the retroinsular cortex of the lateral fissure (Guldin and Grusser, 1998; Chen et al., 2011). Weaker inputs to PE originated in the primary somatosensory cortex (area 3b), and in areas 1 and 3a, confirming some aspects of former studies (Jones et al., 1978; Pons and Kaas, 1986; Darian-Smith et al., 1993).

A salient finding in the present study was that the cortex along the rostral medial bank of the intraparietal sulcus (PEip) is also connected to PE. These connections have not been described previously, mainly because this field has been traditionally included within "area 5." However, the architectonic evidence, together with the distribution of corticocortical (Hatanaka et al., 2001) and corticospinal projections to the cervical segments (Matelli et al., 1998), suggests that PEip is a separate area, which contains an arm representation. Indeed, our data show that this region is heavily labeled after injections in lateral PE (the expected location of the trunk/forelimb representation). By comparison, the dorsocaudal strip of the medial bank (dMIP) (Bakola et al., 2010) contained smaller numbers of labeled cells, and area MIP proper (Colby et al., 1988) was practically devoid of label.

Inputs to PE from area 2 and from the medial bank of the intraparietal sulcus should be considered in relation with the evolutionary history and functional specialization of these fields (Krubitzer and Disbrow, 2008). Although the parietal somatosensory association cortex ("area 5") appeared early in evolution, being shared by all primates, it has been greatly expanded in macaques and humans, especially with the addition of new fields along the intraparietal cortex. According to one interpretation, area 2 is a relatively new addition to unimodal somatosensory cortex, as it is absent in many species of New World monkeys (Padberg et al., 2007). Emergence of new areas in species with larger brains could also stem from a developmental mechanism, which allows subdivision of what would be otherwise a single area (Rosa and Tweedale, 2005). Either way, the expansion of area 5, including specialized subdivisions, the addition of other somatotopic maps (such as area 2), and the formation of distinct connections appear to be functionally linked to the complex 
repertoire of manual behaviors in macaques, as well as humans and some species of New World monkey, such as Cebus.

Connections with motor-related areas

Connections between PE and the primary motor cortex have been reported in some (Leichnetz, 1986; Pons and Kaas, 1986; Ghosh et al., 1987) but not in all cases of previous studies (Jones et al., 1978; Petrides and Pandya, 1984). Our results are more conclusive in showing that projections from M1/F1 to PE are particularly dense, comparable in strength to the connections between M1 and area 2 (Pons and Kaas, 1986). Additional frontal inputs arose from medial area F3/SMA, from the caudal subdivision of dorsal premotor cortex (area F2) and the anterior cingulate cortex, whereas sparse projections were found from the ventral premotor cortex, confirming earlier studies (Jones et al., 1978; Petrides and Pandya, 1984; Luppino et al., 1993; Gerbella et al., 2011).

The substantial cortical input from frontal structures that are involved in movement execution (Barbas and Pandya, 1987; Luppino et al., 1991) is in line with the prevailing role of PE in the planning and guidance of reaching (BattagliaMayer et al., 2003). Indeed, $\sim 70 \%$ of PE neurons in macaques encode reliably movement-related parameters, such as direction and limb position in bodycentered coordinates, properties that are largely shared with motor and premotor neurons (e.g., Archambault et al., 2009, 2011). At the same time, $\mathrm{PE}$ in humans may be associated with a wider set of functions, including the execution of simple movements by different effectors (Heed et al., 2011) and the observation of movements that require accurate and welltimed placement of limbs, such as climbing and locomotion (Abdollahi et al., 2012). Compatible with this observation are findings in cats, which suggest a significant role of the area 5 homolog in the control of walking on uneven terrains (Beloozerova and Sirota, 2003; Marigold and Drew, 2011). In reality, although regarded as separate processes, it has been suggested that reaching has evolved as a behavioral modification of locomotor movements, with both types of actions being subserved by the same sensorimotor network (Georgopoulos and Grillner, 1989). The described robust connections with the medial premotor cortex (F3/SMA) also point to a more general role for PE. Unilateral ablation of F3/SMA disrupts bimanual coordination (Brinkman, 1984), and recordings of neural activity in this area have revealed a complex spectrum of responses, ranging from self-initiated to external cued movements, to movement sequences (Romo and Schultz, 1987; Kurata and Wise, 1988; Tanji and Shima, 1994). In addition, the direct connections between PE and posterior cingulate areas 23 and PEci, which have been implicated in active navigation in humans

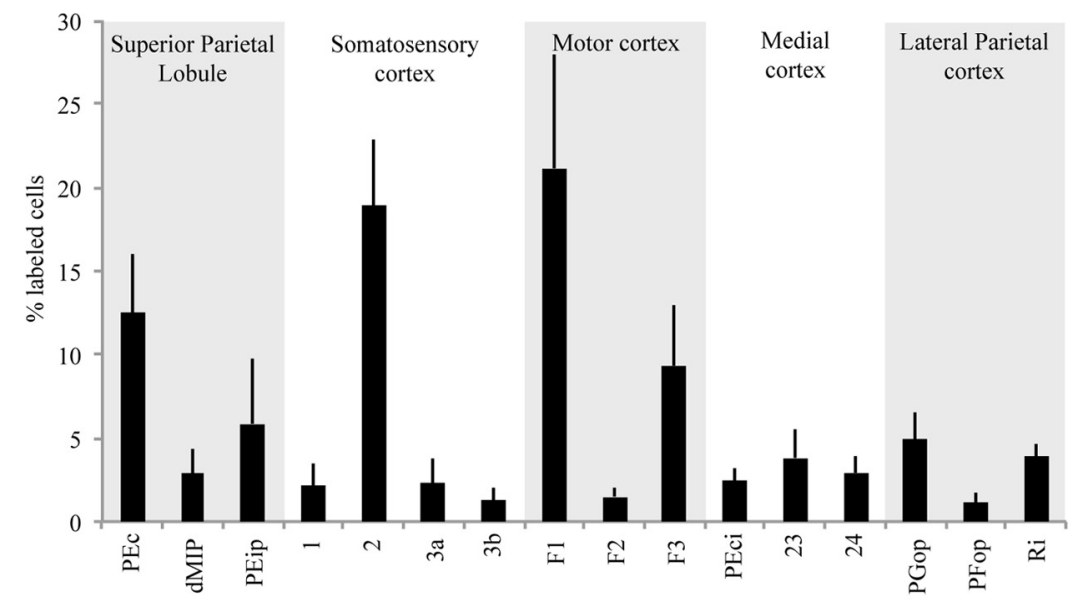

gure 9. Summary of significant $(\geq 1)$ projections to area PE. Top, Average percentages of labeled cells in different cortical of labeled cells and are organized according to their approximate location in the brain (medial to the right, caudal to the bottom). 列 postcentral dimple; PMd, dorsal premotor cortex; PMv, ventral premotor cortex; pos, parieto-occipital sulcus; pre-cd, precentral dimple; ps, principle sulcus; sts, superior temporal sulcus.

and monkeys (Sato et al., 2006, zharv;792010; Wall and Smith, 2008), could be better understood within the broad frame of limb coordination during walking or climbing. Finally, the connections of PE closely resemble those reported in the marmoset, a New World monkey that has a more limited repertoire of hand movements (Burman et al., 2008), again pointing to a wider set of roles in movement coordination in addition to reaching.

\section{References}

Abdollahi RO, Jastorff J, Orban GA (2012) Common and segregated processing of observed actions in human SPL. Cereb Cortex Advance online publication. Retrieved August 23, 2012. doi: 10.1093/cercor/bhs264. CrossRef Medline

Archambault PS, Caminiti R, Battaglia-Mayer A (2009) Cortical mechanisms for online control of hand movement trajectory: the role of the posterior parietal cortex. Cereb Cortex 19:2848-2864. CrossRef Medline Archambault PS, Ferrari-Toniolo S, Battaglia-Mayer A (2011) Online con- 
trol of hand trajectory and evolution of motor intention in the parietofrontal system. J Neurosci 31:742-752. CrossRef Medline

Bakola S, Gamberini M, Passarelli L, Fattori P, Galletti C (2010) Cortical connections of parietal field PEc in the macaque: linking vision and somatic sensation for the control of limb action. Cereb Cortex 20:25922604. CrossRef Medline

Barbas H, Pandya DN (1987) Architecture and frontal cortical connections of the premotor cortex (area 6) in the rhesus monkey. J Comp Neurol 256:211-228. CrossRef Medline

Battaglia-Mayer A, Caminiti R, Lacquaniti F, Zago M (2003) Multiple levels of representation of reaching in the parieto-frontal network. Cereb Cortex 13:1009-1022. CrossRef Medline

Beloozerova IN, Sirota MG (2003) Integration of motor and visual information in the parietal area 5 during locomotion. J Neurophysiol 90:961-971. CrossRef Medline

Borra E, Belmalih A, Calzavara R, Gerbella M, Murata A, Rozzi S, Luppino G (2008) Cortical connections of the macaque anterior intraparietal (AIP) area. Cereb Cortex 18:1094-1111. CrossRef Medline

Bremner LR, Andersen RA (2012) Coding of the reach vector in parietal area 5d. Neuron 75:342-351. CrossRef Medline

Breveglieri R, Galletti C, Gamberini M, Passarelli L, Fattori P (2006) Somatosensory cells in area PEc of macaque posterior parietal cortex. J Neurosci 26:3679-3684. CrossRef Medline

Brinkman C (1984) Supplementary motor area of the monkey's cerebral cortex: short- and long-term deficits after unilateral ablation and the effects of subsequent callosal section. J Neurosci 4:918-929. Medline

Burbaud P, Doegle C, Gross C, Bioulac B (1991) A quantitative study of neuronal discharge in areas 5, 2, and 4 of the monkey during fast arm movements. J Neurophysiol 66:429-443. Medline

Burman K, Palmer S, Gamberini M, Spitzer M, Rosa M (2008) Anatomical and physiological definition of the motor cortex of the marmoset monkey. J Comp Neurol 506:860-876. CrossRef Medline

Burman KJ, Reser DH, Yu HH, Rosa MG (2011) Cortical input to the frontal pole of the marmoset monkey. Cereb Cortex 21:1712-1737. CrossRef Medline

Burton H, Fabri M (1995) Ipsilateral intracortical connections of physiologically defined cutaneous representations in areas $3 \mathrm{~b}$ and 1 of macaque monkeys: projections in the vicinity of the central sulcus. J Comp Neurol 355:508-538. CrossRef Medline

Caminiti R, Chafee MV, Battaglia-Mayer A, Averbeck BB, Crowe DA, Georgopoulos AP (2010) Understanding the parietal lobe syndrome from a neurophysiological and evolutionary perspective. Eur J Neurosci 31: 2320-2340. CrossRef Medline

Cavada C, Goldman-Rakic PS (1989a) Posterior parietal cortex in rhesus monkey: I. Parcellation of areas based on distinctive limbic and sensory corticocortical connections. J Comp Neurol 287:393-421. CrossRef Medline

Cavada C, Goldman-Rakic PS (1989b) Posterior parietal cortex in rhesus monkey: II. Evidence for segregated corticocortical networks linking sensory and limbic areas with the frontal lobe. J Comp Neurol 287:422-445. CrossRef Medline

Chen A, DeAngelis GC, Angelaki DE (2011) Convergence of vestibular and visual self-motion signals in an area of the posterior sylvian fissure. J Neurosci 31:11617-11627. CrossRef Medline

Colby CL, Gattass R, Olson CR, Gross CG (1988) Topographical organization of cortical afferents to extrastriate visual area PO in the macaque: a dual tracer study. J Comp Neurol 269:392-413. CrossRef Medline

Culham JC, Cavina-Pratesi C, Singhal A (2006) The role of parietal cortex in visuomotor control: what have we learned from neuroimaging? Neuropsychologia 44:2668-2684. CrossRef Medline

Darian-Smith C, Darian-Smith I, Burman K, Ratcliffe N (1993) Ipsilateral cortical projections to areas $3 \mathrm{a}, 3 \mathrm{~b}$, and 4 in the macaque monkey. J Comp Neurol 335:200-213. CrossRef Medline

Duffy FH, Burchfiel JL (1971) Somatosensory system: organizational hierarchy from single units in monkey area 5. Science 172:273-275. CrossRef Medline

Falchier A, Clavagnier S, Barone P, Kennedy H (2002) Anatomical evidence of multimodal integration in primate striate cortex. J Neurosci 22:57495759. Medline

Ferraina S, Bianchi L (1994) Posterior parietal cortex: functional properties of neurons in area 5 during an instructed delay reaching task within different parts of space. Exp Brain Res 99:175-178. Medline
Friedman DP, Jones EG, Burton H (1980) Representation pattern in the second somatic sensory area of the monkey cerebral cortex. J Comp Neurol 192:21-41. CrossRef Medline

Galletti C, Fattori P, Kutz DF, Gamberini M (1999) Brain location and visual topography of cortical area V6A in the macaque monkey. Eur J Neurosci 11:575-582. CrossRef Medline

Galletti C, Gamberini M, Kutz DF, Baldinotti I, Fattori P (2005) The relationship between $\mathrm{V} 6$ and PO in macaque extrastriate cortex. Eur J Neurosci 21:959-970. CrossRef Medline

Gallyas F (1979) Silver staining of myelin by means of physical development. Neurol Res 1:203-209. Medline

Gamberini M, Passarelli L, Fattori P, Zucchelli M, Bakola S, Luppino G, Galletti C (2009) Cortical connections of the visuomotor parietooccipital area V6Ad of the macaque monkey. J Comp Neurol 513:622642. CrossRef Medline

Georgopoulos AP, Grillner S (1989) Visuomotor coordination in reaching and locomotion. Science 245:1209-1210. CrossRef Medline

Gerbella M, Belmalih A, Borra E, Rozzi S, Luppino G (2011) Cortical connections of the anterior (F5a) subdivision of the macaque ventral premotor area F5. Brain Struct Funct 216:43-65. CrossRef Medline

Geyer S, Matelli M, Luppino G, Zilles K (2000) Functional neuroanatomy of the primate isocortical motor system. Anat Embryol 202:443-474. CrossRef Medline

Ghosh S, Brinkman C, Porter R (1987) A quantitative study of the distribution of neurons projecting to the precentral motor cortex in the monkey (M. fascicularis). J Comp Neurol 259:424-444. CrossRef Medline

Graziano MS, Cooke DF, Taylor CS (2000) Coding the location of the arm by sight. Science 290:1782-1786. CrossRef Medline

Gregoriou GG, Borra E, Matelli M, Luppino G (2006) Architectonic organization of the inferior parietal convexity of the macaque monkey. J Comp Neurol 496:422-451. CrossRef Medline

Guldin WO, Grüsser OJ (1998) Is there a vestibular cortex? Trends Neurosci 21:254-259. CrossRef Medline

Hatanaka N, Nambu A, Yamashita A, Takada M, Tokuno H (2001) Somatotopic arrangement and corticocortical inputs of the hindlimb region of the primary motor cortex in the macaque monkey. Neurosci Res 40:9-22. CrossRef Medline

Heed T, Beurze SM, Toni I, Röder B, Medendorp WP (2011) Functional rather than effector-specific organization of human posterior parietal cortex. J Neurosci 31:3066-3076. CrossRef Medline

Huffman KJ, Krubitzer L (2001) Area 3a: topographic organization and cortical connections in marmoset monkeys. Cereb Cortex 11:849-867. CrossRef Medline

Hutchins KD, Martino AM, Strick PL (1988) Corticospinal projections from the medial wall of the hemisphere. Exp Brain Res 71:667-672. CrossRef Medline

Hyvärinen J (1982) Posterior parietal lobe of the primate brain. Physiol Rev 62:1060-1129. Medline

Johnson PB, Ferraina S, Bianchi L, Caminiti R (1996) Cortical networks for visual reaching: physiological and anatomical organization of frontal and parietal lobe arm regions. Cereb Cortex 6:102-119. CrossRef Medline

Jones EG, Coulter JD, Hendry SH (1978) Intracortical connectivity of architectonic fields in the somatic sensory, motor and parietal cortex of monkeys. J Comp Neurol 181:291-347. CrossRef Medline

Kalaska JF (1996) Parietal cortex area 5 and visuomotor behavior. Can J Physiol Pharmacol 74:483-498. CrossRef Medline

Krubitzer LA, Kaas JH (1990) The organization and connections of somatosensory cortex in marmosets. J Neurosci 10:952-974. Medline

Krubitzer L, Disbrow E (2008) The evolution of parietal areas involved in hand use in primates. In: The senses: a comprehensive reference (Kaas J, Gardner E, eds), pp 183-214. London: Elsevier.

Kurata K, Wise SP (1988) Premotor and supplementary motor cortex in rhesus monkeys: neuronal activity during externally- and internallyinstructed motor tasks. Exp Brain Res 72:237-248. CrossRef Medline

Lacquaniti F, Guigon E, Bianchi L, Ferraina S, Caminiti R (1995) Representing spatial information for limb movement: role of area 5 in the monkey. Cereb Cortex 5:391-409. CrossRef Medline

Legendre P (2005) Species associations: the Kendall coefficient of concordance revisited. J Agric Biol Environ Stat 10:226-245. CrossRef

Leichnetz GR (1986) Afferent and efferent connections of the dorsolateral precentral gyrus (area 4, hand/arm region) in the macaque monkey, with comparisons to area 8. J Comp Neurol 254:460-492. CrossRef Medline 
Lewis JW, Van Essen DC (2000a) Mapping of architectonic subdivisions in the macaque monkey, with emphasis on parieto- occipital cortex. J Comp Neurol 428:79-111. CrossRef Medline

Lewis JW, Van Essen DC (2000b) Corticocortical connections of visual, sensorimotor, and multimodal processing area in the parietal lobe of the macaque monkey. J Comp Neurol 428:112-137. CrossRef Medline

Lewis JW, Burton H, Van Essen DC (1999) Anatomical evidence for the posterior boundary of area 2 in the macaque monkey. Somatosens Motor Res 10:382-390.

Luppino G, Matelli M, Camarda RM, Gallese V, Rizzolatti G (1991) Multiple representations of body movements in mesial area 6 and the adjacent cingulate cortex: intracortical microstimulation study in the macaque monkey. J Comp Neurol 311:463-482. CrossRef Medline

Luppino G, Matelli M, Camarda R, Rizzolatti G (1993) Coricocortical connections of area F3 (SMA-proper) and area F6 (pre-SMA) in the macaque monkey. J Comp Neurol 338:114-140. CrossRef Medline

Marconi B, Genovesio A, Battaglia-Mayer A, Ferraina S, Squatrito S, Molinari M, Lacquaniti L, Caminiti R (2001) Eye-hand coordination during reaching: I. Anatomical relationships between parietal and frontal cortex. Cereb Cortex 11:513-527. CrossRef Medline

Marigold DS, Drew T (2011) Contribution of cells in the posterior parietal cortex to the planning of visually guided locomotion in the cat: effects of temporary visual interruption. J Neurophysiol 105:2457-2470. CrossRef Medline

Markov NT, Misery P, Falchier A, Lamy C, Vezoli J, Quilodran R, Gariel MA, Giroud P, Ercsey-Ravasz M, Pilaz LJ, Huissoud C, Barone P, Dehay C, Toroczkai Z, Van Essen DC, Kennedy H, Knoblauch K (2011) Weight consistency specifies regularities of macaque cortical networks. Cereb Cortex 21:1254-1272. CrossRef Medline

Matelli M, Luppino G, Rizzolatti G (1991) Architecture of superior and mesial area 6 and the adjacent cingulate cortex in the macaque monkey. J Comp Neurol 311:445-462. CrossRef Medline

Matelli M, Govoni P, Galletti C, Kutz DF, Luppino G (1998) Superior area 6 afferents from the superior parietal lobule in the macaque monkey. J Comp Neurol 402:327-352. CrossRef Medline

Mesulam MM, Rosene DL (1979) Sensitivity in horseradish peroxidase neurohistochemistry: a comparative and quantitative study of nine methods. J Histochem Cytochem 27:763-773. CrossRef Medline

Morecraft RJ, Cipolloni PB, Stilwell-Morecraft KS, Gedney MT, Pandya DN (2004) Cytoarchitecture and cortical connections of the posterior cingulate and adjacent somatosensory fields in the rhesus monkey. J Comp Neurol 469:37-69. CrossRef Medline

Mountcastle VB, Lynch JC, Georgopoulos A, Sakata H, Acuna C (1975) Posterior parietal association cortex of the monkey: command function for operations within extrapersonal space. J Neurophysiol 38:871-908. Medline

Murray EA, Coulter JD (1981) Supplementary sensory area: the medial parietal cortex in the monkey. In: Cortical sensory organization (Woolsey CN, ed), pp 167-195. Clifton, NJ: Humana.

Padberg J, Franca JG, Cooke DF, Soares JG, Rosa MG, Fiorani M Jr, Gattass R, Krubitzer L (2007) Parallel evolution of cortical areas involved in skilled hand use. J Neurosci 27:10106-10115. CrossRef Medline

Palmer SM, Rosa MG (2006) A distinct anatomical network of cortical areas for analysis of motion in far peripheral vision. Eur J Neurosci 24:23892405. CrossRef Medline

Pandya DN, Seltzer B (1982) Intrinsic connections and architectonics of posterior parietal cortex in the rhesus monkey. J Comp Neurol 204:196210. CrossRef Medline

Passarelli L, Rosa MG, Gamberini M, Bakola S, Burman KJ, Fattori P, Galletti C (2011) Cortical connections of area V6Av in the macaque: a visualinput node to the eye/hand coordination system. J Neurosci 31:17901801. CrossRef Medline

Pearson RC, Powell TP (1978) The cortico-cortical connections to area 5 of the parietal lobe from the primary somatic sensory cortex of the monkey. Proc R Soc Lond B Biol Sci 200:103-108. CrossRef Medline
Petrides M, Pandya DN (1984) Projections to the frontal cortex from the posterior pariental region in the rhesus monkey. J Comp Neurol 228:105116. CrossRef Medline

Pons TP, Kaas JH (1986) Corticocortical connections of area 2 of somatosensory cortex in macaque monkeys: a correlative anatomical and electrophysiological study. J Comp Neurol 248:313-335. CrossRef Medline

Pons TP, Garraghty PE, Cusick CG, Kaas JH (1985) The somatotopic organization of area 2 in macaque monkeys. J Comp Neurol 241:445-466. CrossRef Medline

Reser DH, Burman KJ, Yu HH, Chaplin TA, Richardson KE, Worthy KH, Rosa MG (2012) Contrasting patterns of cortical input to architectural subdivisions of the area 8 complex: a retrograde tracing study in marmoset monkeys. Cereb Cortex Advance online publication. Retrieved June 26, 2012. doi: 10.1093/cercor/bhs177. CrossRef Medline

Robinson CJ, Burton H (1980) Organization of somatosensory receptive fields in cortical areas 7b, retroinsula, postauditory, and granular insula of M. fascicularis. J Comp Neurol 192:69-92. CrossRef Medline

Romo R, Schultz W (1987) Neuronal activity preceding self-initiated or externally timed arm movements in area 6 of monkey cortex. Exp Brain Res 67:656-662. CrossRef Medline

Rosa MG, Tweedale R (2005) Brain maps, great and small: lessons from comparative studies of primate visual cortical organization. Philos Trans R Soc Lond B Biol Sci 360:665-691. CrossRef Medline

Rosa MG, Palmer SM, Gamberini M, Tweedale R, Piñon MC, Bourne JA (2005) Resolving the organization of the New World monkey third visual complex: The dorsal extrastriate cortex of the marmoset (Callithrix jacchus). J Comp Neurol 483:164-191. CrossRef Medline

Sakata H, Takaoka Y, Kawarasaki A, Shibutani H (1973) Somatosensory properties of neurons in superior parietal cortex (area 5) of the rhesus monkey. Brain Res 64:85-102. CrossRef Medline

Sato N, Sakata H, Tanaka YL, Taira M (2006) Navigation-associated medial parietal neurons in monkeys. Proc Natl Acad Sci U S A 103:17001-17006. CrossRef Medline

Sato N, Sakata H, Tanaka YL, Taira M (2010) Context-dependent placeselective responses of the neurons in the medial parietal region of macaque monkeys. Cereb Cortex 20:846-858. CrossRef Medline

Seal J, Gross C, Bioulac B (1982) Activity of neurons in area 5 during a simple arm movement in monkeys before and after deafferentation of the trained limb. Brain Res 250:229-243. CrossRef Medline

Sheskin D (2004) Handbook of parametric and nonparametric statistical procedures, Ed 3. Boca Raton, FL: Chapman and Hall/CRC.

Siegel S (1956) Nonparametric statistics for the behavioral sciences. New York: McGraw-Hill.

Snyder LH, Batista AP, Andersen RA (1998) Change in motor plan, without a change in the spatial locus of attention, modulates activity in posterior parietal cortex. J Neurophysiol 79:2814-2819. Medline

Tanji J, Shima K (1994) Role for supplementary motor area cells in planning several movements ahead. Nature 371:413-416. CrossRef Medline

Taoka M, Toda T, Iwamura Y (1998) Representation of the midline trunk, bilateral arms, and shoulders in the monkey postcentral somatosensory cortex. Exp Brain Res 123:315-322. CrossRef Medline

Taoka M, Toda T, Iriki A, Tanaka M, Iwamura Y (2000) Bilateral receptive field neurons in the hindlimb region of the postcentral somatosensory cortex in awake macaque monkeys. Exp Brain Res 134:139-146. CrossRef Medline

Van Essen DC, Drury HA, Dickson J, Harwell J, Hanlon D, Anderson CH (2001) An integrated software suite for surface-based analyses of cerebral cortex. J Am Med Inform Assoc 8:443-459. CrossRef Medline

Vogt BA, Vogt L, Farber NB, Bush G (2005) Architecture and neurocytology of monkey cingulate gyrus. J Comp Neurol 485:218-239. CrossRef Medline

von Bonin G, Bailey P (1947) The neocortex of Macaca mulatta. Urbana, IL: University of Illinois.

Wall MB, Smith AT (2008) The representation of egomotion in the human brain. Curr Biol 18:191-194. CrossRef Medline 